Original Article

\title{
Disaster preparedness of Mutare city council, Zimbabwe
}

Matunhu Jephias and Sellinah Mabhureni

Tugwi Mukosi Multidisciplinary Research Institute (TMMRI) of the Midlands State University, P.O. Box 100, Zvishavane, Zimbabwe

doi:

\begin{abstract}
The study was conducted in Mutare City in Manicaland province in Zimbabwe. The study was prompted by the effects of cyclone Idai which had unprecedented effects on lives and development assets in other parts of the province. The principal objective of this study was to gauge the disaster preparedness of the City in terms of the Sendai Framework for Disaster Risk Reduction. A purposively selected sample of 30 research participants was involved. Interviews and observation were the main data gathering tools. The findings were that the City was not disaster prepared. A combination of policy guidelines, training and disaster education, equipment, coordination and infrastructure are the main factors against which disaster preparedness was assessed. An innovative all-inclusive disaster management system is being recommended for the City.
\end{abstract}

KEYWORDS

Disaster,

Preparedness, Mutare

City.

\section{CORRESPONDING}

AUTHOR

Matunhu Jephias

jephiasmatunhu@yahoo.com

\section{INTRODUCTION}

Between January and October 2005 over 97490 people succumbed to disasters globally and 88117 of them in natural disasters (Braine 2005). The effect of disasters is worse in developing countries; in 2005 an earthquake in the Kashmir region claimed more than 87000 lives in Pakistan and over 1300 more in India (Braine 2005). Between 1980 and 2010 Zimbabwe (Prevention Web 2012) suffered 35 natural disasters, which claimed 6,448 deaths cumulatively. The 35 disasters can be disaggregated as follows, 6 droughts, 7 floods, 2 storms, and 20 epidemics.

In the country, cyclone Dineo claimed 117 lives and left 109 people injured by lightning and cyclone Idai claimed 185 lives, left 330 people missing and 270,000 in need of aid. The Zimbabwe Civil Protection Act, chapter 10.06 defines disaster as a major accident or event causing destruction, pollution or scarcity of essential supplies; or disruption of essential services or influx of refugees or plague or epidemic of disease; that threatens the life or well-being of a community.

Disaster preparedness is activities and measures taken in advance to ensure effective response to the impact of disasters, including the issuance of timely and effective early warnings and the short-term removal of people and property from a threatened location (UN ISDR 2005). The Constitution of Zimbabwe states that Government and local authorities have the duty to ensure that their communities are safe in line with the UN Sustainable Development Goals and the Sendai Framework. The study was conducted in Mutare, which attained city status in 1971.The City is the provincial capital of Manicaland which is in the eastern part of the country of Zimbabwe. "Umtali" was its colonial name until 1982. 


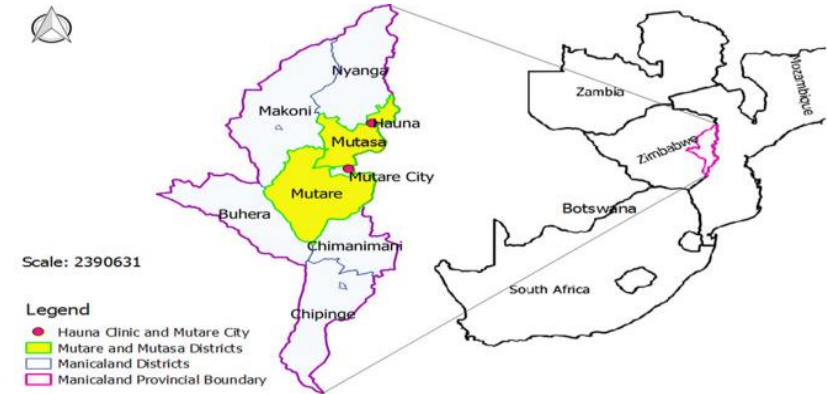

Fig (1) Map of Mutare; Source: Mutare City Website

The City is also affectionately referred as "kumakomoyo" meaning a "place of many mountains". Mutare has a population of 188243 people (Zimbabwe National Statistics Agency 2012) and is located at 8 kilometers from the Zimbabwe-Mozambique border. Manicaland province is one of the most disaster-prone areas in Zimbabwe. In 2000the Province was hit by tropical cyclone Eline. In 1991 the Nyanga public transport road accident claimed 86 lives and in 2019 the city of Mutare was struck by a heat wave of up to 42 degree Celsius. The Sendai Framework for Disaster Risk Reduction notes that disasters are inevitable and that they rob society of lives. The Framework encourages communities to be adequately prepared for disasters. If not adequately prepared for, Mutare City may not achieve sustainable development goals (SDGs) nether will attain Vision 2030.The need for this study is emphasized by FAO's (2018) warning that hazard events will become more common, more frequent, and more volatile. The object of the study was to establish the capacity of Mutare City Council to deal with disasters and to gauge the inclusivity of the Council's state of preparedness to handle disasters.

\section{Review of Related Literature}

Disaster preparedness is the second stage of the disaster management cycle. It concerns programs aimed to achieve an acceptable level of readiness to respond to an emergency. The stage involves developing long term and short-term strategies through programs that build up both technical and managerial capacity of governments, organizations, and communities. Disaster preparedness ensures that strategic reserves of food, services, equipment, water, medicines and any other essentials are maintained in cases of a disaster. Preparedness (Col 2007) is readiness to respond to an emergency based on planning, training and exercise. It also includes actions designed to enhance the aptitude to undertake emergency actions as well as the ability to engage in post-disaster restoration and early recovery activities.

The process of developing an effective disaster preparedness capability reflects legislative and institutional arrangements. Coordination structures, contingency and response plans are important considerations in disaster preparedness (Phiri et al. 2014). Without adequate accurate information and communication systems, the process is bound to fail. The process requires substantial time and resources as well as a genuine sense of ownership of the process by all partners. Effective disaster preparedness includes arrangements that ensure that all the resources and services needed to cope with the effects of a disaster are efficiently mobilized and deployed in an emergency.

Early warning is a major component of ( $\mathbf{U N}$ ISDR 2005) disaster preparedness. The warning systems need to involve the communities at risk, facilitate public education and awareness of risks, and effectively disseminate warnings (Canton 2007; Benson \& Clay 2004). A preparedness dashboard is required to keep a nation or community in a constant state of preparedness The Hyogo Framework for Action 2005-2015, itself a precursor of the Sendai Framework for Disaster Risk Reduction 2015-2030, encouraged the development of early warning systems that are people-centered, and in particular systems whose warnings are timely and understandable to those at risk (Gumbo 2007).The Sendai Framework seeks to curtail the effects of disasters to human life by focusing on seven targets and four priorities of actions. 
Levels of disaster preparedness collates with level of knowledge, warning systems in place, resources capacities among others (Hales $\boldsymbol{e t}$ al. 2012). Although no economy can adequately prepare for disasters, the level of disaster preparedness is low in most poor economies (Maguire 2007). No individual or individual community can provide resources that are equal or above the catastrophe because disasters are unique in that they strike differently. Availability of resources alone does not guarantee effective disaster management, but proper coordination and utilization of resources gives the best results in disaster management.

\section{MATERIALS AND METHODS}

Data were collected from residents who had stayed in the City for at least five years. A continuous stay in the City was considered long enough to give the respondents enough lived experiences of the state of disaster preparedness of the local authority. Qualitative research methodology was adopted because of its flexibility. The methodology gives room for greater spontaneity and adaptation of the interaction between researchers and the study participants (Mack et al. 2005).

The open nature of the questions gives the participants the opportunity to respond in their own words. Babbie (2010) in concurrence with Chisaka (2013) add the following advantages of qualitative research: (i) research is conducted in the natural setting of social factors, (ii) actor's perspective (the insider or emic view) is emphasized, (iii) researcher is the primary instrument for data collection and analysis, (iv) product of a qualitative study is richly descriptive, and (v) research allows researchers to make an interpretation of what they see, hear and understand. The methodology enabled the researchers to make reliable conclusions on disaster preparedness of Mutare City. Council employees, Civil Protection Unit, Non-Governmental
Organizations, and the residents of the City were the target population.

Purposive and snowballing sampling were used to build a study sample and informant interviews, focus group discussions and direct observations were the data collection tools. Interviews (Brunt 1997; Borg \& Gall 1996; Amaratunga et al. 2002) are favorable in different research areas where in-depth data is required. Subject viewpoints (Flick 2006) are expressed better in an openly designed interview situation than in a standardized interview. The interviews were conducted in a less formal way. Interviews allow probing of interesting responses and observation of the non-verbal responses (Polit \& Hungler 2004). Below is a tabulation of the actual interviews conducted against the planned ones.

Table (1) Interviews Conducted

\begin{tabular}{|l|c|c|}
\hline Targeted group & $\begin{array}{l}\text { Targeted } \\
\text { interviews }\end{array}$ & $\begin{array}{l}\text { Interviews } \\
\text { conducted }\end{array}$ \\
\hline Mutare City Council & 20 & 30 \\
\hline Civil Society Organizations & 5 & 3 \\
\hline Civil Protection Unit & 5 & 2 \\
\hline Mutare Residents & 10 & 19 \\
\hline Total & $\mathbf{4 0}$ & $\mathbf{5 4}$ \\
\hline
\end{tabular}

Direct observation was undertaken because it allows verification of what is being reported and what is holding on the ground (Nut-brown 2007). The study undertook a field tour of the City. Field researchers (Neuman 1997) listens to members, in order to "climb into their skin or walk in their shoes". Non-verbal cues were noted and recorded during the interviews. Four twelve members focus group meetings were conducted as follows: (i) Dangamvura - Beit Hall 19 September 2019 at $1230 \mathrm{hrs}$ to $2 \mathrm{pm}$, (ii) Chikanga 21 September 2019 at 1700 hrs-1815hrs, (iii) Hob House- 22 September 2019 at $1300 \mathrm{hrs}-1405 \mathrm{hrs}$, and (iv) Sakubva-23 September 2019 at 1305hrs-1404 hrs. The teams were representative in terms of gender, disability status and age group. A wealth of data was also obtained from secondary sources like 
minutes of Council meetings, relevant websites and Mutare Facebook page.

Approval to conduct the study was granted by the Chamber Secretary of Mutare City Council on 24th of September 2019. Potential participants were informed of the right to refuse to participate in the study in addition to withdraw at any stage if they felt uncomfortable with continuing to participate in the study. The participants were also informed that all information they supply was to be handled in strict confidence. Interview records were kept in a password protected computer and handwritten transcriptions were to be shredded after publication of the study. The participants were also assured that their identities were to remain anonymously. All the participants consented to participating in the study. Informed consent (Creswell 2013) influences the quality of information given by the respondents. Below is an illustration of the Framework adopted for this study.

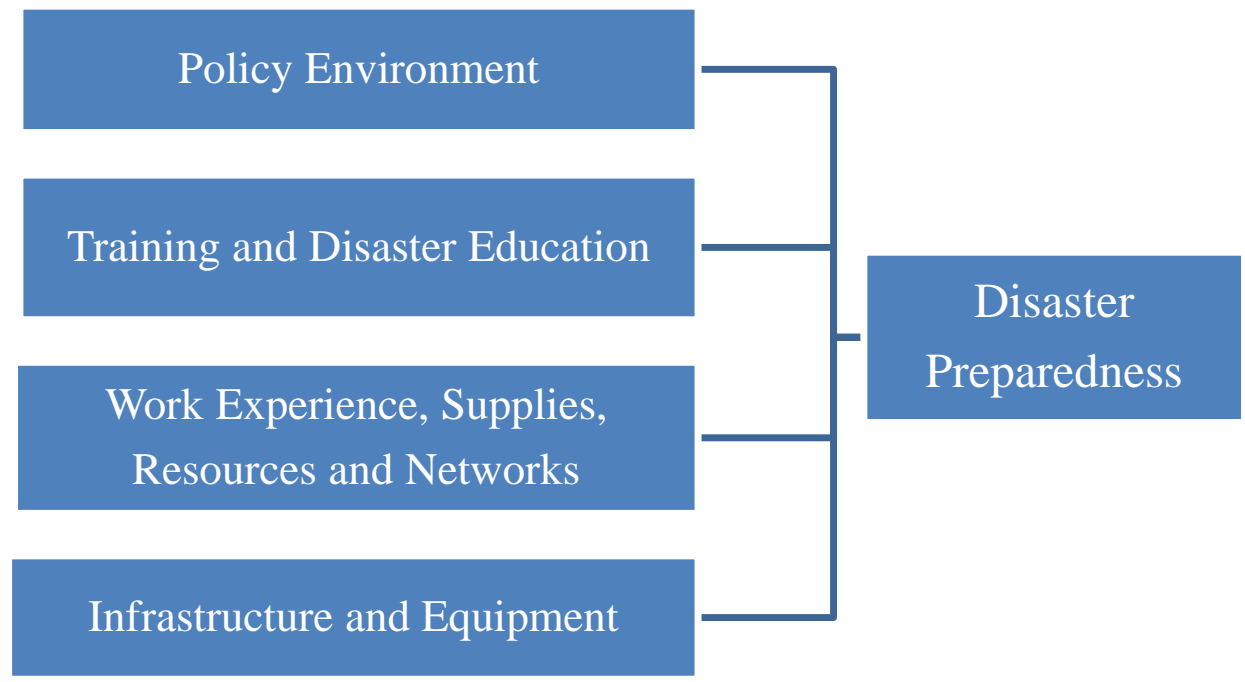

Fig (2) Theoretical Framework; Source: Adopted and adjusted from Miles and Huberman (1994)

The Framework of analysis emphasizes the importance of a combination of policy guidelines, training and disaster education, equipment, coordination and infrastructure in building a resilient disaster preparedness structure. These factors augur well with the Sendai Framework guidelines.

\section{RESULTS AND DISCUSSION}

\section{Analysis on disaster preparedness constraints}

It was gathered that disaster preparedness constraints were emanating from policy guidelines, training and disaster education, equipment, and coordination as illustrated below.

\section{Policy Guidelines}

Responses in Table 2 reflects that there is no clear-cut policy guideline in the City's disaster preparedness, which is contrary to the provisions of the Sendai Framework for Disaster Risk Reduction 2015-2030. The City Council disaster policy could not be availed to the researchers on request. One of the key informants (Council employee) confessed ignorance of the existence of the policy. 'I have been in the City Council for over a decade, and I have never asked for the policy neither did anyone inform me of its existence.' (Mutare City Council Employee during an interview).

A local authority with no shared disaster policy is bound to fail to manage disasters. 
Policies outline roles and responsibilities of stakeholders before, during and after a disaster and such policies should be (Gumbo 2006) should be communicated to all stakeholders. Calamities increases in case where residents are not knowledgeable of what to do and how to do it in disaster situations. The policies must be done and reviewed (Kahn \& Barondness 2008) in consultations with those who are affected by them. The Mutare City Management was blamed for failing to involve ordinary residents in disaster policy making. A female respondent opinioned that the City Council would prefer to go without a shared policy to avoid being held accountable when disasters strike. The problem is with the Civil Protection Act (Mavhura 2016) whose key weaknesses include inactive community participation, unavailability of dedicated and adequate resources and centralization of power and resources. Uncontrolled development within the City is partly a result of the lack of inclusivity in disaster policy making processes (Interview Respondent).
The other respondents attributed the policy problem to corruption. A youthful respondent claimed, 'Corruption in the Council contributes to the high vulnerability of the City to disasters. For instance, wetlands are being sold for infrastructure development ... we know of story-buildings which were constructed in such places ... Such buildings may not be able to withstand floods...' The Sendai Framework for Disaster Risk Reduction 2015-2030 emphasizes the importance of human life when taking developmental decisions.

A Respondent from a local academic institution shared, "there is no adequate enforcement of bylaws . . . many of these structures are in high hazard risk areas... in case of earthquakes the buildings will not withstand tremor . . .' In Chimanimani, the local authority authorized a settlement to develop in Copa valley and when cyclone Idai hit the area (Matunhu 2019) the entire settlement was wiped out.

Table (2) Responses on Disaster Preparedness Constraints

\begin{tabular}{|l|c|c|c|c|c|}
\hline \multirow{2}{*}{\multicolumn{1}{c|}{ Constraints }} & \multicolumn{5}{c|}{ Respondents } \\
\cline { 2 - 6 } & Key Informant & $\begin{array}{l}\text { Red Cross } \\
\text { Society }\end{array}$ & CPU & $\begin{array}{l}\text { Disaster } \\
\text { Managers }\end{array}$ & Residents \\
\hline Policy guidelines & + & + & $*$ & $*$ & + \\
\hline Training and disaster education & + & - & + & + & + \\
\hline Equipment & + & - & + & + & + \\
\hline Coordination & + & + & + & + & + \\
\hline Infrastructure & + & + & + & + & + \\
\hline Personnel & - & $*$ & + & $*$ & + \\
\hline+ Means it is a problem, * & It is not a problem, - Not a big problem. & \\
\hline
\end{tabular}

\section{Training and Disaster Education}

Responses in Table 2 show that adequate training and disaster education are lacking. It is problematic in that resources are inadequate to mount training sessions. A tour of Sakubva High density Suburb and other residential areas to check the effects of inadequate training on disaster preparedness revealed that most houses did not have fire escape routes and that most of them had burglar bars and screen doors which would make it near impossible for the occupants to escape in case of a fire hazard. All the houses did not have fire extinguishers. In thirteen out of the thirty houses inspected, the 
electric sockets were not properly secured with some having naked wires. The Respondents did not see the link between the status quo and disasters. In public schools, 11 of them did not have functional water hydrants, six had buildings with no fire escape routes and none of them had conducted fire drills in the last five years. All the premises where not ensured against disasters.

The Respondents refuted to have received coordinated disaster education and training either by Civil Protection Unit (CPU) or the City Council. One of the interviewees noted, 'the only meetings the local council has had with the community were budget related with little or no special attention to disaster preparedness'. The Sendai Framework of Disaster Risk Reduction can only be achieved with the help of the right education and training. Three male respondents shared the belief that disaster education by the local authority was not necessary; 'no amount of education on disaster preparedness will avert the spiritual world's resolve to affect in time' One of them narrated, 'the best education and training on disaster preparedness is in believing in God because $\mathrm{He}$ is the giver and taker of everything. His wisdom and protecting Hand will not fail to protect His chosen ones no matter the intensity of a disaster'.

The responses above indicate that the community has different understandings about disaster preparedness and this calls for persuasion to achieve improved understanding of disasters and disaster preparedness. Right education and training empower communities to take informed actions to prevent disasters and to take wise decisions when disasters strike.

One female respondent narrated how lack of training and education can make a bad situation worse. She explained thus, "During the recent cyclone Idai disaster, I happened to be visiting Chimanimani, the epicenter of the cyclone. What I witnessed in Chimanimani was horrific. Many lives, livestock and property could have been saved if people knew how to behave during the crisis... women and children perished in the floods because someone somewhere did not take the right decisions ... In my view, disaster training and education should be taught from childhood". With no training and the right education, the City increases its vulnerability to calamities which is akin to reversing developmental gains. Disasters (Dube et al. 2018) result in increased poverty especially in poor communities.

\section{Equipment and Facilities}

The Mutare Fire Department is located about 400 meters from the Civic Centre. The Department trains its fire fighters; however, staff turnover is high. One of the key informants noted, 'due to poor remuneration caused by diminishing inflows, the City is experiencing skills flight and a general inability to attract and retain qualified town planners, disaster experts, doctors, engineers and other technicians. National Government departments responsible for disasters are also facing the same plague'.

Obsolete equipment was observed at the station, which makes it difficult for the City to preserve human life when disasters strike. One of the officers manning the Station indicated that much of the equipment was either worn out or outdated and that shortage of facilities has prompted some people to adopt bad practices. A resident of the City shared thus, 'In Sakubva sewerage spillage is the order of the day. At most commuter omnibus terminuses and at flea markets people are now using plastic toilets'. The informant defined plastic toilet as whereby people use plastic bags to relieve themselves in and throw them away.

The study established that disaster preparedness of the City is also influenced by poor revenue collection. Key informants reported; thus, 'Council is owed huge amounts in rent, water bills and rates. The interviewees believed that funds are being lost because Council Finance Department is porous. 
Table (3) Summary of Challenges at the Station

\begin{tabular}{|c|c|}
\hline Item & Narrative \\
\hline Service Vehicles & $\begin{array}{l}\text { - The Fire Brigade does not have adequate vehicles. } \\
\text { - The Council is relying on donated fire fighters from Peter. } \\
\text { - The vehicles are-Cohel DAF } 5000 \text { liters, Chevrolet 1,500 liters } \\
\text { and a Fuso } 1.200 \text { liters. } \\
\text { - The water carrying capacity vehicle, Chevrolet is below minimum } \\
\text { standard (Respondent at the Station) } \\
\text { - The Fire engines are malfunction and unreliable }\end{array}$ \\
\hline Firefighting delivery holes & $\begin{array}{l}\text { - Warn out firefighting delivery holes. } \\
\text { - The holes connect the horse from the fire engine car to the branch }\end{array}$ \\
\hline Ambulances & $\begin{array}{l}\text { - Council had one functional ambulance. } \\
\text { - The Council needs four ambulances }\end{array}$ \\
\hline Dormitory beds & $\begin{array}{l}\text { - } \text { A dormitory was available. } \\
\text { - The beds and mattresses were worn out and dirty. } \\
\text { - These poses a risk especially respiratory disease. }\end{array}$ \\
\hline Breathing apparatus / sets & $\begin{array}{l}\text { - No functioning breathing sets at the station. } \\
\text { - Firefighters use the sets in firefighting or when in a mine shaft. } \\
\text { - The worn-out breathing sets were donated by operation Florian }\end{array}$ \\
\hline Ropes & $\begin{array}{l}\text { - Ropes are used in pit or mine shaft rescue. } \\
\text { - The ropes cannot be relied on they are also a threat to the disaster } \\
\text { personnel who will be using them. }\end{array}$ \\
\hline Portable pumps and rescue pumps & - No portable pumps and rescue pumps to use in disaster situations. \\
\hline Extension ladders & $\begin{array}{l}\text { - No extension ladders at the Fire station } \\
\text { - Extension ladders are used on storey-buildings, mine shafts, } \\
\text { boreholes and anywhere that might require extension ladders. }\end{array}$ \\
\hline
\end{tabular}

The interviewee at the Station shared: 'we submitted requests for equipment and facilities to our procurement officer and made several followups to no avail. We are risking our lives and that of our clients . . . most of the water hydrants dotted around the City are not operational . .'A senior Council employee noted; 'disaster preparedness has not been given priority especially by the donor community. Most of the donor funds are allocated to relief and reconstruction work . . . As Council, we cannot divert the funds to disaster preparedness'. An investment specialist in the City noted that the Government of Zimbabwe recently declared Mutare a Special Economic Zone and that sound disaster preparedness would boost investor confidence in Mutare as an investment destination. The research established that some fire extinguishers were last serviced years ago. For instance, the extinguisher pictured below had been marked "replace the cap" since May 2011.
The fire extinguisher was at the Council Revenue Hall where a huge traffic of people reports for inquiries and sometimes for paying bills. In the event of an inferno, many people including property could perish. The Sendai Framework requires that such equipment be always kept in proper working condition.

\section{Coordination}

Key informants reported that disaster meetings are held monthly at provincial level. Minutes of the meetings could not be availed to the researchers. Effective disaster preparedness requires participation and coordination of various sectors and disciplines such as the three tiers of government (national, provincial, and local), private sector, community, non-governmental organizations, community-based organizations, research institutions and universities and the public

(Bongo et al. 2013). 
In Zimbabwe, as in Costa Rica and other nations, the Law outlines the roles and responsibilities of each of the government and non-government partners involved in preparedness and response. Coordination approaches effectively capitalize on existing indigenous capacities which are usually (Stern 2007) sensitive to gender, cultural and other context-specific issues that can undermine or empower particular groups and individuals to take locally based action.

A Respondent for from the City noted, 'collaboration and co-ordination ensure that resources are accessed at different places and, as such, proper coordination between the agencies is important to bring together dispersed resources and the knowledge and skills required to build resilient built environments within cities'.

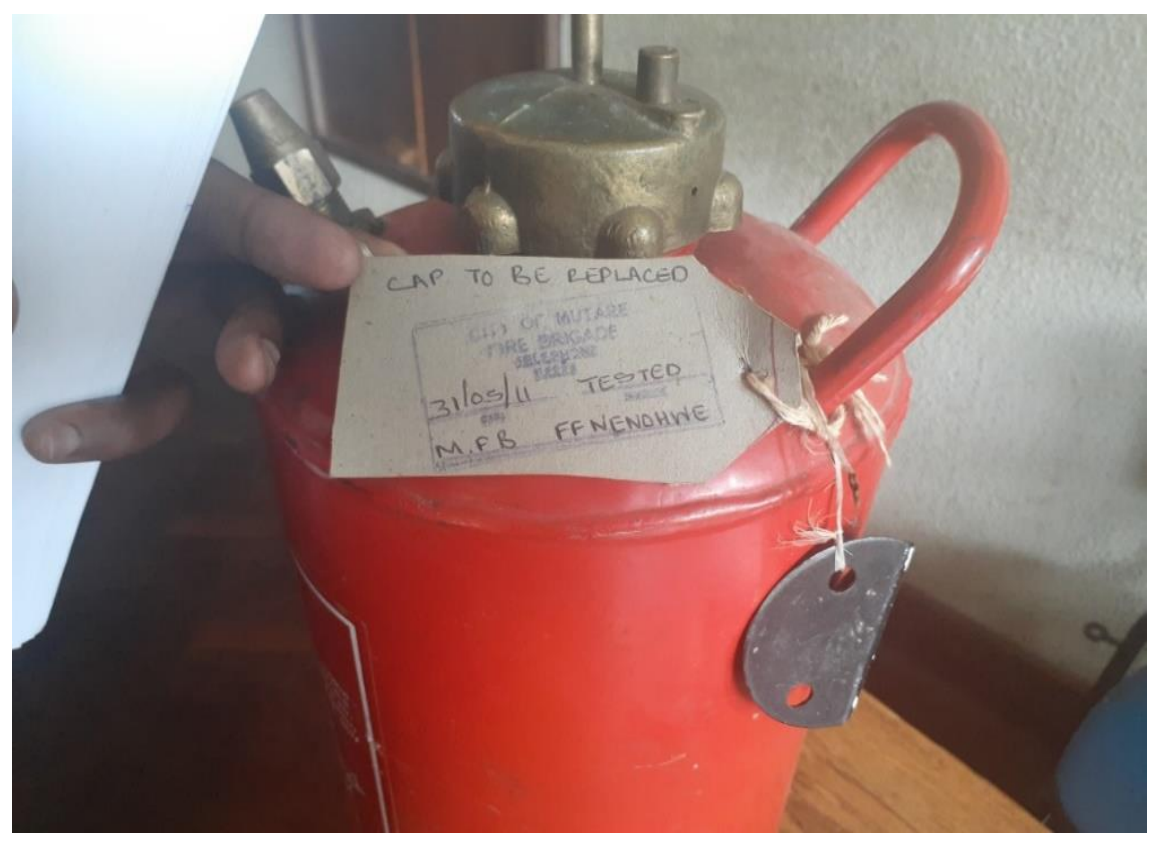

Fig (3) Un-serviced Fire Extinguisher

Interviews revealed that direct consultations with the local communities is minimal and that there are no disaster sub committees in the residential areas. A senor resident of the City explained: 'In our suburb, we do not have a disaster committee neither am I aware of a suburb with one. . . Coordination is a subject to be raised where these committees exist'. The Council is of the opinion that communities speak through their elected leaders who sit in Council meetings. However, a resident of the City working in a university noted, 'elected council representatives rarely convene meetings on disaster preparedness.' Community involvement allows identification of community values and resources which can be considered in disaster planning. Incorporation of locals' perspectives (Kahn \& Barondness 2008) into decision and activities helps to ensure that changes in vulnerability and perception of risk are recognized and factored into institutional processes, risk assessments, and other programs and policies. A ward councilor indicated that not many residents are interested in attending meetings and that Council decided to reach the residents through posters and the print media. The strategy is good; however, it does not have a feedback mechanism. There must be increased focus on community-based approaches (World Bank 2004) noting that disaster preparedness is less effective without the participation of the vulnerable communities.

A key informant claimed that understaffing affects coordination; "there is only one Fire brigade office 
servicing Manicaland province. The Office is being manned by a staff compliment of twenty -ten per shift instead of fifteen." Interviews with the key informants at the City Council revealed that poor working conditions were forcing skilled staff to leave for greener pastures and that the few available qualified employees are under resourced and over stretched to allow smooth coordination with government and non-government departments.

\section{CONCLUSIONS}

The study made the following conclusions concerning disaster preparedness in Mutare:

- Disaster infrastructure development was lagging behind.

- Equipment such as vehicles was limited, with some of the equipment having gone for long before they were serviced.

- The Council is not mounting disaster education and training to the residents, and

- There is no inclusive disaster policy for the Council and that there are no local disaster subcommittees in the residential areas.

\section{RECOMMENDATIONS}

The Council is advised to mount civic education on disasters and disaster preparedness given that the City to floods and other disasters. The education could be offered through the print and electronic media. The City has a community radio station 'Diamond' which could be used to teach the resident on disaster preparedness in all the languages being spoken in the area. It is further recommended that frequent fire drills be conducted in all public properties so as to regularly check the disaster preparedness level of the City. The residents are encouraged to form community disaster champions whose role is to ensure that each household is disaster prepared. Messages about disasters and disaster preparedness could be spread at funerals, wedding parties, church and political meetings as well as through WhatsApp platforms. Further researches are encouraged on preparedness of other local authorities in Zimbabwe as well as on disaster preparedness programs funding options.

\section{REFERENCES}

Amaratunga D. et al. (2002). "An integrative review of the built environment discipline's role in the development of society's resilience to disasters", International Journal of Disaster Resilience in the Built Environment, 1(1): 1124.

Babbie E. (2010). The Practice of Social Research. Belmont: Wadsworth.

Benson C. and Clay E. J. (2004). Understanding the Economic and Financial Impacts of Natural Disasters. New York, World Bank.

Bongo P. P., Chipangura P., Sitholem and Moy F. (2013). A rights-based analysis of disaster risk reduction framework in Zimbabwe and its implications for policy and practice. Jamba Disaster Risk Studies, 5(1).

Borg W. R., and Gall M. D. (1996). Educational research: An introduction $\left(6^{\text {th }} \mathrm{ed}\right.$.). New York, Longman.

Braine T. (2006). Was 2005 the year of natural disasters? Bulletin of the World Health Organization Past Issues, 84 (1) 1-80.

Canton L. G., (2007). Emergency Management: Concepts and Strategies for Effective Programs: Libre Digital.

In www.ezproxy.aut.ac.nz Retrieved 12 December 2019

Chisaka B. C. (2013). The Qualitative Paradigm in Action Research Some Practical Ideas for Educational Practice. Harare, Save the Children.

Civil Protection Act. (2001). Civil Protection Act. Parliament of Zimbabwe Document (Chapter 10.06). Harare. 
Col J. M. (2007). Managing Disasters: The Role of Local Government. Public Administration Review, 1(3): 112-125.

Creswell J. W. (2013). Qualitative inquiry and Research Design: Choosing among Five Approaches, Washington, Sage Publications.

Dube E., Mtapiri O. and Matunhu J. (2018). Flooding and poverty: Two interrelated social problems impacting rural development in Tsholotsho District of Matabeleland North Province in Zimbabwe. Jamba: Journal of Disaster Risk Studies, 10 (2) 1-7.

FAO (2018). Resilience to natural hazards and resulting disasters. In www.fao.org/resilience/areas-of-work/naturalhazards (Accessed 1 October 2020)

Flick U. (2006). An Introduction to Qualitative Research, (3rd edition). London, Sage.

Gumbo D. (2007). Zimbabwe: Country Case Study on Domestic Policy Frameworks for Adaptation in the Water Sector: OECH Global Forum on Sustainable Development.

Hales B., Walzer N., and Calvin J. (2012). Community responses to disasters: A foundation for Recovery. Community Development, 43(5): 540-549.

Kahn L. H. and Barondness J. A. (2008). Preparing for Disaster: Response Matrices in the USA and UK. Journal of Urban Health, 85: 910-922.

Matunhu J. (2019). Climate Change induced Cyclone Idai: Narratives of Women in Chimanimani District, Zimbabwe. Paper presented at Lund University, Sweden on 2-3 October 2019.
Mavhura E. (2016). Disaster Legislation: A critical review of the Civil Protection Act of Zimbabwe. Natural Hazards, 80: 605-621.

Miles M. B. and Hubermann A. M. (1994). Conceptual framework for the study of factors affecting teachers' use of technology. In www.wiredspace.wits.ac.za/jspui/bitstream (Accessed 12 September 2020).

Neuman W. L. (1997).Social Research Methods: Qualitative and Quantitative Approaches. ( $3^{\text {rd }}$ Ed.), Boston, Allyn and Bacon.

Nut-brown C. (2007). A Student's Guide to Methodology, ( $3^{\text {rd }}$ Ed.). London, Peter Clough - University of Brighton.

Phiri S., Mudavanhu C. and Mucherera B. (2014). The complexity of Maladaptation, Strategies to disasters: The case of Muzarabani, Zimbabwe. Jamba: Journal of Disaster Risk Studies, 6: 1-12.

Polit D. and Hungler B. (1999). Nursing Research: Principle and Method, 6th ed.; Philadelphia: Lippincott Company.

Prevention Web. (2012). "Zimbabwe - Disaster Statistics." In www.preventionweb.net/english/countries/stat istics (accessed 28 November 2019).

Stern N. (2007). The Economics of Climate Change: The Stern Review. Cambridge, Cambridge University Press.

UN-ISDR (2005). "Disaster Risk Reduction Efforts in Zimbabwe." In www.unisdr.org/2005/mdgs-drr/nationalreports/Zimbabwe-report (accessed 11 October 2019).

Zimbabwe National Statistics Agency (2012). Census 2012 Preliminary Report. Zimbabwe National Statistics Agency, Harare. 